\title{
Definitive Contraception: Trends in a Ten-year Interval
}

\section{Contracepção definitiva: tendências em um intervalo de dez anos}

\author{
Cecília Maria Ventuzelo Marques ${ }^{1}$ Magda Maria do Vale Pinto Magalhães ${ }^{1}$ \\ Maria João Leal da Silva Carvalho ${ }^{1,2}$ Giselda Marisa Costa Carvalho ${ }^{1}$ \\ Francisco Augusto Falcão Santos Fonseca ${ }^{1}$ Isabel Torgal ${ }^{1,2}$ \\ ${ }^{1}$ Gynecology A Service, Centro Hospitalar e Universitário de Coimbra, \\ Praceta Prof. Mota Pinto, Coimbra, Portugal \\ 2 Department of Medicine, Universidade de Coimbra, \\ Coimbra, Portugal \\ Address for correspondence Cecília Maria Ventuzelo Marques, MD, \\ Serviço de Ginecologia A, Centro Hospitalar e Universitário de \\ Coimbra, Praceta Prof. Mota Pinto, 3000-075 Coimbra, Portugal \\ (e-mail: ceciques@gmail.com).
}

Rev Bras Ginecol Obstet 2017;39:344-349.

\begin{abstract}
Objective To evaluate the trends in definitive contraception in a ten-year interval comprising the years 2002 and 2012.

Method Retrospective analysis of the tubal sterilization performed in our service in 2002 and 2012, analyzing the demographic characteristics, personal history, previous contraceptive method, definite contraception technique, effectiveness and complications.

Results Definitive contraception was performed in 112 women in 2002 (group 1) and in 60 women in 2012 (group 2). The groups were homogeneous regarding age, parity, educational level and personal history. The number of women older than 40 years choosing a definitive method was more frequent in group 1, 49.1\% $(n=55)$; for group 2 , the rate was $34.8 \%(n=23)(p=0.04)$. The time between the last delivery and the procedure was $11.6 \pm 6.2$ and $7.9 \pm 6.4$ years $(p=0.014)$ in 2002 against 2012 respectively. In 2002, all patients performed tubal ligation by laparoscopic inpatient regime. In 2012, the bilateral placement of the Essure (Bayer Corporation, Whippany, $\mathrm{N}$, US) device was suggested to $56.1 \%(n=37)$ of the patients, while laparoscopy was suggested to $43.9 \%(n=29)$ of them. All women who underwent laparoscopic sterilization had the procedure successfully completed using silastic rings. The overall bilateral device placement rate for the Essure was $91.6 \%$, with only one complication

\section{Keywords}

- definitive contraception

- tubal ligation

- office hysteroscopy

- essure reported. All Essure procedures were performed in an outpatient setting; for the laparoscopy, this rate was $79 \%(n=15)$. No intentional pregnancies occurred until this date.

Conclusions There is a trend in the decrease in definitive contraception over the years in our institution, maybe as a result of the development of long-acting reversible contraceptives. The hysteroscopic procedure has become a frequent option, as it is performed in an office setting without anesthesia, being a well-tolerated, minimal invasive method.
\end{abstract}

received

October 6, 2016

accepted

March 6, 2017

published online

May 4, 2017
DOI https://doi.org/

$10.1055 / \mathrm{s}-0037-1602706$ ISSN 0100-7203.
Copyright $\odot 2017$ by Thieme Revinter

Publicações Ltda, Rio de Janeiro, Brazil
License terms

()(1) $\Theta \circledast$ 


\section{Resumo}

\section{Palavras-chave \\ - contracepção definitiva \\ - laqueadura tubária \\ - histeroscopia \\ - essure}

Objetivo Avaliar as tendências da contracepção definitiva feminina num intervalo de 10 anos, 2002 e 2012.

Métodos Análise retrospectiva das mulheres submetidas a esterilização em 2002 e 2012 no Serviço de Ginecologia de um hospital em Portugal, atendendo às caraterísticas demográficas, antecedentes pessoais, método contraceptivo prévio, técnica de contracepção efetuada, eficácia e complicações ocorridas.

Resultados Foram submetidas a contracepção definitiva 112 mulheres em 2002 (grupo 1), e 66 em 2012 (grupo 2). Os grupos eram semelhantes na idade, paridade, nível educacional e antecedentes pessoais. O número de mulheres com mais de 40 anos que optou por um método definitivo foi superior no grupo $1,49,1 \%(n=55)$, versus $34,8 \%(n=23)$ no grupo $2(p=0,04)$. O tempo decorrido entre o último parto e o procedimento foi de $11.6 \pm 6.2$ anos e $7.9 \pm 6.4$ anos $(p=0.014)$ em 2002 versus 2012, respetivamente. Em 2002, todas as mulheres foram submetidas a laqueação tubária em regime de internamento. Em 2012, a colocação bilateral do Essure (Bayer Corporation, Whippany, NJ, EUA) foi proposta para $56,1 \%(n=37)$ das pacientes, enquanto a laparoscopia foi proposta para $43,9 \%(n=29)$ delas. A laqueação por laparoscopia foi realizada com sucesso em todos os casos com anéis de silastic. A taxa de colocação bilateral do Essure foi de $91,6 \%$, tendo sido registrada uma complicação. Todos os procedimentos com Essure foram realizados em regime de ambulatório, enquanto que tal se verificou em $79 \%(n=15)$ daquelas pacientes submetidas a laparoscopia. Não ocorreram gravidezes não intencionais.

Conclusão Parece haver uma tendência para a diminuição da esterilização como opção contraceptiva, provavelmente devido à disponibilidade de diversos métodos contraceptivos de longa duração aliada aos benefícios não contraceptivos. A opção pelo dispositivo Essure, mais recentemente, é justificada pela sua realização em contexto de consultório, sem anestesia, sendo um método minimamente invasivo e bem tolerado.

\section{Introduction}

Female sterilization is a birth control method performed worldwide, and $19 \%$ of women who were married or in stable relationships relied on it in $2015{ }^{1}$ In Portugal, $2.6 \%$ of women in reproductive age performed tubal ligation. ${ }^{2}$

Since 1995, a decline in the rates of female sterilization has been observed. This is hypothesized to be a result of demographic, economic, social, and cultural factors, such as delayed childbirth and improved access to long-acting reversible contraceptives (LARCs). ${ }^{3}$ Despite this fact, female tubal sterilization is one of the most common interventions in the gynecologic practice, after cesarean section and surgical abortion. ${ }^{4}$

Several methods for achieving permanent sterilization have been described, and subsequently modified to improve the success rates, using simplified surgical techniques and reducing the postoperative pain and the hospital stay. Nowadays, female sterilization can be performed using an abdominal or hysteroscopic approach. ${ }^{4}$

The sterilization approach can be performed immediately postpartum, or as an interval procedure, unrelated to a pregnancy. Approximately $50 \%$ of female sterilizations are per- formed immediately postpartum..$^{5}$ Sterilization follows $8 \%$ to $9 \%$ of live births, most often at the time of cesarean delivery. ${ }^{3}$

The first procedures for sterilization were performed through formal laparotomy incisions, frequently in association with a caesarean section. In the late 1950s, the possibility of approaching the tubes through a much reduced incision was recognized. ${ }^{6}$ Since 1995 , the adoption of laparoscopy as interval sterilizations has become more common, and has shifted the procedure from the inpatient to the ambulatory setting. The current methods of female sterilization include a variety of occlusion techniques, including bipolar coagulation, ligation, or mechanical occlusion techniques using spring clips or silastic rings.

The hysteroscopic route avoids the transabdominal route, and the risks associated with the entrance in the peritoneal cavity are thereby avoided. It is supposed to result in less morbidity and a quicker return to normal activities. Another advantage of the hysteroscopic sterilization compared with the laparoscopic approach is the reduced need for anesthesia, with the possibility of sterilization in the office setting. These advantages make hysteroscopic sterilization a good option for women with contraindications to laparoscopy, or who just wish to avoid incisional surgery or general anesthesia. 
The Essure (Bayer Corporation, Whippany, NJ, US) device is a metal and polymer micro-insert that is $4 \mathrm{~cm}$ long and 1 to $2 \mathrm{~mm}$ wide when deployed. It consists of an inner coil of stainless steel and polyethylene terephthalate (PET) fibers and an outer coil of nickel-titanium (nitinol). It comes loaded in a single-use delivery system. The device is placed under hysteroscopic guidance in the proximal fallopian tube. The coil initially is in a tightly wound state, and when it is deployed, it expands in order to anchor the insert in the tube. After placement, the PET fibers stimulate benign tissue growth that surrounds and infiltrates the device over the course of several weeks, resulting in tubal occlusion. ${ }^{7} \mathrm{~A}$ disadvantage of this type of sterilization is that it is not immediately effective. Because tubal fibrosis occurs over time, interim contraception should be used until a 3-month post-procedure hysterosalpingogram/sonography can be performed to confirm bilateral tubal occlusion.

The purpose of our study was to observe the trends in definitive contraception in a ten-year interval, 2002 and 2012, considering demographic data, technical approach and efficacy.

\section{Material and Methods}

We performed a retrospective study comparing the techniques used for definitive contraception in 2002 (group 1) and in 2012 (group 2) in our department (-Fig. 1). The demographic and social parameters, the previous contraceptive methods, and the rates of efficacy and complications were analyzed.

Laparoscopic female sterilization in $2002(n=112)$ was performed in the standard inpatient format: patients were admitted on the morning of the previous day of surgery, and underwent tubal ligation under general anesthesia on the next day, with discharge on the following day.

In $2012(n=66)$, the patients to whom laparoscopic sterilization without comorbidity was indicated, and those who lived less than one hour from the hospital, were admitted in an ambulatory setting, on the morning of the surgery, and underwent sterilization under general anesthesia, with discharge at the end of the same day. All Essure procedures were performed in a dedicated hysteroscopy clinic by the same person. Continuous flow hysteroscopy was employed using a $5 \mathrm{~mm}$ hysteroscope (Karl-Storz, Tuttlingen, Germany). The placement was performed according to the manufacturer's instructions. When the hysteroscopy was performed, the Essure device, placed at the tip of the disposable plastic handle, was inserted through the hysteroscope's working channel. After approaching the tubal ostium, the micro-insert was placed in the intramural part of the tube, expanded so that between 3 and 8 loops of the spring remained visible and detached from the handle. The remaining catheter was then retrieved out of the hysteroscope. The same operation was repeated in the contralateral tube. Intramuscular analgesia with nonsteroidal anti-inflammatory drugs (NAIDs) was generally administered prior to the procedure, if no allergies were documented. Three months after that, a transvaginal sonography was used to confirm the position of the tubal devices, or a hysterosalpingogram in selective cases.

Data analysis was performed with the Statistical Package for the Social Sciences (SPSS, IBM Corp. Armonk, NY) software, version 20.0 .

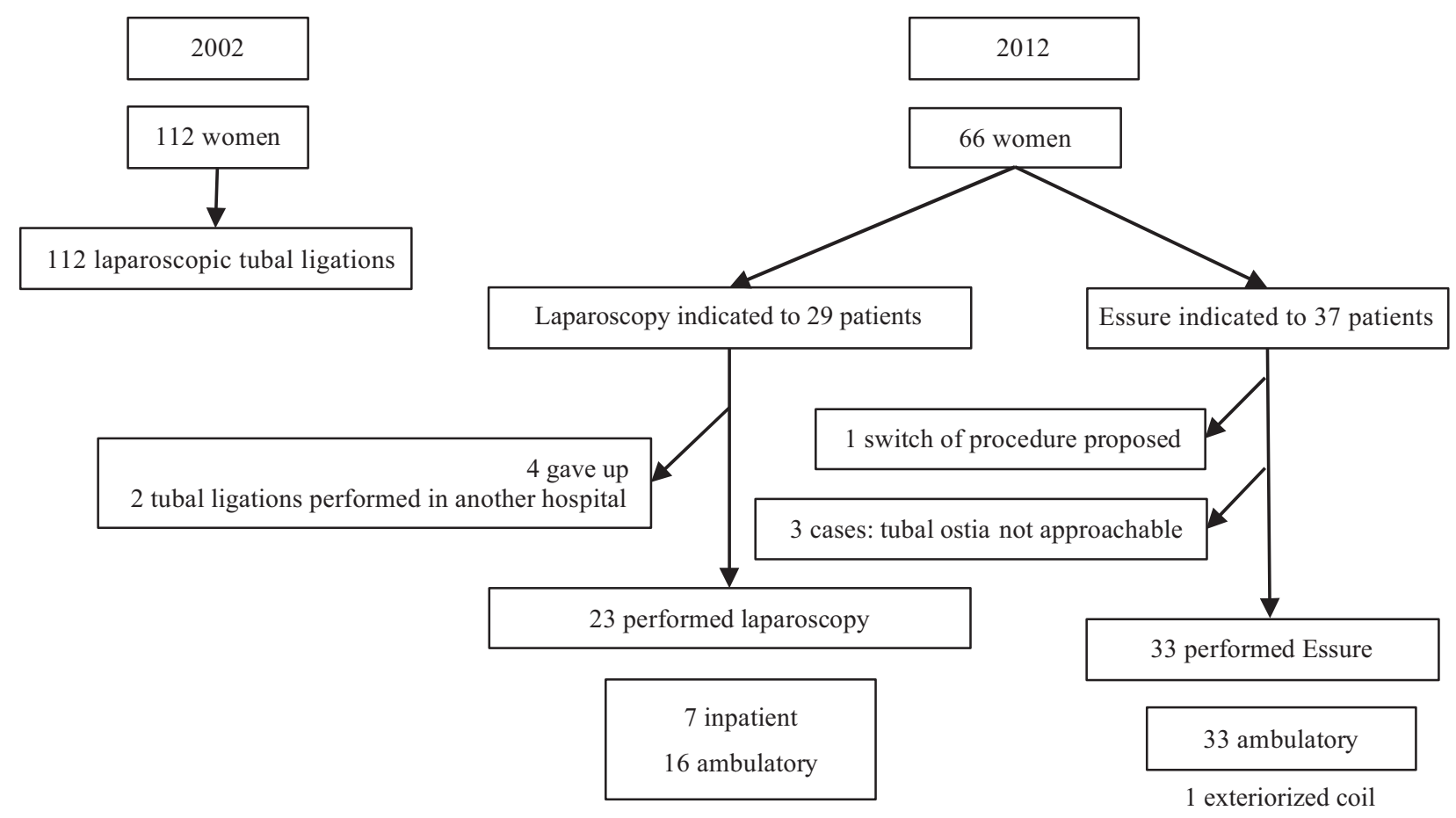

Fig. 1 Patient tree of the women included in the study. 
Table 1 Demographic data

\begin{tabular}{|l|l|l|l|}
\hline & 2002-Group 1 & 2012-Group 2 & $p$ \\
\hline $\mathrm{N}$ & 112 & 66 & - \\
\hline Caucasian & $112(100 \%)$ & $65(98 \%)$ & n.s. \\
\hline Mean age (min-max) & $40(25-50)$ & $39(21-45)$ & $<0.05$ \\
\hline$\geq 40$ years old & $55(49 \%)$ & $23(35 \%)$ & n.s. \\
\hline Educational level (> 7th grade) & $53(56.6 \%)$ & $37(56 \%)$ & n.s. \\
\hline Married or in a stable relationship & $104(92.9 \%)$ & $58(87.9 \%)$ & n.s. \\
\hline Parity (mean [min-max]) & $1.96(0-5)$ & $1.95(0-5)$ & n.s. \\
\hline Age at the last delivery (years; mean [min-max]) & $28.3(17-39)$ & $30(18-40)$ & 0.05 \\
\hline $\begin{array}{l}\text { Mean time between the last delivery and the definitive } \\
\text { contraception (years; mean [min-max]) }\end{array}$ & $12.19(0-27)$ & $7.93(0-24)$ & \\
\hline
\end{tabular}

Abbreviation: n.s., non-significant.

\section{Results}

Definitive contraception was indicated to 112 women in 2002 and to 66 in 2012. The median age was similar in both groups $(40.0 \pm 4.1$ in group 1 , against $39.0 \pm 4.4$ in group 2$)$, and women older than 40 years were more frequent in group 1 $(49.1 \% ; n=55)$ than in group $2(34.8 \% ; n=23), p=0.04$. In both groups, the main population was composed of women who were married or in stable unions ( - Table $\mathbf{1}$ ).

Hypertension was one of the most common medical disorders, with a rate of $18.8 \%$ in group 1 and $18.2 \%$ in group 2. History of venous thromboembolism was reported by $2.7 \%$ $(n=3)$ of the women in 2002 , and by $7.6 \%(n=5)$ of the women in 2012. Varicose veins were diagnosed in $27.7 \%$ $(n=31)$ of the patients in group 1 , and in $13.6 \%(n=9)$ of the patients in group 2 (-Table 2 ).

The mean parity was also similar in both groups. The last delivery occurred $11.6 \pm 6.2$ years before the sterilization in group 1 , and $7.9 \pm 6.4$ years in group $2(p=0.014)$.

The contraceptive methods used by these women when they decided for a definitive method were mainly combined oral contraceptives (group 1: $42.9 \%$; group 2: $43.9 \%$ ), followed by the cooper intrauterine device (group 1: $27.7 \%$; group 2: $27.3 \%$ ), and the male condom (group 1: $19.6 \%$; group 2: $7.6 \%$ ).
A contraindication or non-adaption to hormonal contraceptives and a LARC was present in $31.3 \%(n=35)$ and $9.8 \%$ $(n=11)$ of the patients in 2002, and in $18.2 \%(n=11)$ and $19.7 \%(n=12)$ of the patients in 2012.

In 2002, tubal ligation by laparoscopy was indicated to all women, $98.2 \%$ ( $n=98)$ with silastic rings, and $1.8 \%(n=2)$ by bipolar coagulation. All the patients were operated in an inpatient setting; no complications were documented. In $12 \%$ ( $n=14$ ) of them, other procedures were performed in the same operative time. In the post-operative visit ( 6 weeks after the surgery), no late complications were referred. One woman regretted having undergone the procedure, performed a tubal anastomosis in 2007, and later had a successful pregnancy. No cases of unintended pregnancies were documented in the remainder of the group.

In 2012, laparoscopic sterilization was indicated to $43.9 \%$ $(n=29)$ of the patients. Out of these, $10.3 \%(n=3)$ gave up, 3.4\% $(n=2)$ decided to perform it in another hospital, and $3.3 \%(n=1)$ opted for a levonorgestrel intrauterine system (LNG-IUS). Silastic rings were used in 95.6\% $(n=22)$ of the women, and bipolar coagulation, in $4.3 \%$ $(n=1)$ of them. No immediate complications occurred; $30.4 \%(n=7)$ of the procedures were performed in an inpatient setting (-Fig. 1). For these, the mean hospital

Table 2 Medical conditions

\begin{tabular}{|l|l|l|l|}
\hline & $2002-G r o u p 1$ & $2012-G r o u p ~ 2$ & $p$ \\
\hline Arterial hypertension & $21(19 \%)$ & $12(18 \%)$ & n.s. \\
\hline Varicose veins & $31(28 \%)$ & $9(14 \%)$ & 0.02 \\
\hline Venous thromboembolism & $3(3 \%)$ & $5(8 \%)$ & n.s. \\
\hline Obesity & $20(18 \%)$ & $14(21 \%)$ & n.s. \\
\hline Tabagism & $13(12 \%)$ & $6(9 \%)$ & n.s. \\
\hline Other pathologies & $8(7 \%)$ & $7(11 \%)$ & n.s. \\
\hline No pathologies & $29(26 \%)$ & $22(33 \%)$ & n.s. \\
\hline
\end{tabular}

Abbreviation: n.s., non-significant. 
stay after the procedure was 2.8 days. In the post-operative visit, 6 weeks after the surgery, no late complications were referred, and all the patients were satisfied with the method.

The Essure device was indicated to $56.1 \%(n=37)$ of the patients in group 2 . The overall bilateral placement rate was $91.6 \%$ (33/36). In one case, one of the coils exteriorized the day after the procedure, and a new one was placed. There were no complications recorded immediately after the procedure, and there was no need of recovery. The procedure in general was well-tolerated. In the three cases of failure, the reasons were left tubal ostium occlusion in one case, and non-approachable tubal ostia in two cases. In all of these cases, the previous contraceptive method was the male condom. The tubal occlusion was performed by laparoscopy in one case, by mini-laparotomy in another, and the third woman opted for a subcutaneous implant.

All patients kept the previous contraceptive method until the 3 months' visit. The 3 months' sonography was doubtful in one case. The patient performed a hysterosalpingogram that showed bilateral occlusion. The rate of failure was $0 \%$ until this date.

\section{Discussion}

The number of women to whom sterilization was indicated decreased from 2002 to 2012 . The study compared the years of 2002 and 2012, and the number of patients, nevertheless, is limited. In Europe, according to the latest data from the United Nations, female sterilization rates declined from 4.5 to 3.7 between 1994 and 2015. ${ }^{1}$ In Portugal, this rate declined from $4.6 \%$ to $2.6 \%$ between 2005 and 2015 . $^{2}$

Nowadays, there is a variety of modern methods that provide long-acting reversible contraception and have other benefits besides contraception. The efficacy of the LARC, the intrauterine device (IUD) and the subcutaneous implant appears to be comparable to that of the permanent contraception. The first-year failure rate of the copper IUD device is $1 \%$; for the LNG-IUS, it is $0.2 \%$; and for the subcutaneous implant, it is $0.01 \%{ }^{8}$ Those rates are similar to the rates of the definitive methods (laparoscopic sterilization with silastic ring: $0.5 \%{ }^{9}$; Essure: $0.04 \%^{10}$ ). The LNG-IUS and the contraceptive implant have important noncontraceptive benefits, including potentially decreased or absent menstrual blood loss and decreased dysmenorrhea. ${ }^{11}$

This study is retrospective; it compares two different years and, consequently, the methods of sterilization used in different surgical approaches. The procedures were performed in different subjects, who may also have different perceptions of tolerance and satisfaction. Finally, the environment in which the procedures were performed (hospital admission and general anesthesia against outpatient office and no anesthesia) influence the patients' choice and satisfaction with the procedure itself.

The groups were very similar in mean age, parity and personal history. Group 2 had more women older than 40 years old looking for a definitive method, and the mean time between the last delivery and the procedure was shorter in group 2 than in group 1 . As a result of the delayed maternity, women complete the reproductive plan later and take less time to seek a definitive procedure. ${ }^{3}$

Among the techniques available in 2002, the standard procedure was tubal ligation by laparoscopy, which was performed in all women. No complications were documented, and the rate of satisfaction with the method was of $100 \%$. In 2012, the number of patients who chose Essure was larger than the number of patients who chose laparoscopic sterilization. Hysteroscopic sterilization offers obvious advantages to the patients, since it is a less invasive and well-tolerated method, performed in an office setting. However, insertion of the Essure system requires learning; therefore, all of the procedures were performed by an experienced senior physician. The rate of bilateral placement was high, $91.6 \%$, similar to the rate reported in the literature, which is between $92 \%$ and $99 \%{ }^{7,12-17}$ Most of the women who opted for the Essure (53.3\%) were using a combined oral contraceptive that controls the menstrual cycle, facilitating the procedure.

Although both methods could be performed in an ambulatory setting, the Essure requires less time from the patient, with no need of recovery and a quicker return to the daily activities.

Despite the elevated price of the Essure, which is around $922.5 €$ in Portugal, the total costs of the laparoscopic tubal ligation, namely nursing, operative room and ancillary costs, are higher compared with hysteroscopic sterilization.

The most commonly reported complications of the Essure are malpositioning, chronic pain, unintended pregnancy, infection, uterine or tubal perforation, device expulsion, and device migration. Nickel allergy was also reported. ${ }^{18}$ None of these adverse events have been recorded in our study.

Regarding the analgesia used in the placement of the Essure, there is a variety of studies that evaluate the pain during the procedure, and different analgesia protocols were used in them. Thiel et $\mathrm{al}^{19}$ compared intravenous sedation with oral analgesia, and concluded that they are equivalent.

Although sterilization is meant to be permanent, some women will express regret and request a reversal. The pregnancy rates after tubal ligation reversal range from $68 \%$ in women with a previous electrocautery procedure to $72 \%$ in women with silastic rings. ${ }^{20}$ Regarding the Essure, successful pregnancies were reported after micro-insert removal with tubal implantation to correct the interstitial occlusion by the laparotomy approach. ${ }^{21}$

A modified Essure implant (ESS505), with a synthetic polymer hydrogel seal on the distal end of the insert that when exposed to an aqueous environment causes the distal end to swell, potentially allowing immediate tubal occlusion, was created. This technique has been developed to avoid the 3 months' contraception and confirmatory test. The preliminary results revealed that this modified device was able to acutely occlude the targeted fallopian tube in the majority of cases $(93 \%)^{22}$

Finally, considering the theory of the tubal origin of ovarian cancer and the hypothesis that salpingectomy may decrease the risk of it $^{23}$, bilateral complete salpingectomy is now being considered as a method of sterilization that could potentially decrease the risk of ovarian cancer. Theoretically, 
bilateral salpingectomy is $100 \%$ effective, although at least 1 case report describes a pregnancy after bilateral tubal removal. $^{24}$ Thus, in women undergoing tubal ligation for purposes of sterilization, counseling should include a discussion of complete fallopian tube removal, or opportunistic salpingectomy. Women should be informed that the potential benefit is theoretic, that there is the potential for increased surgical risks and compromised ovarian blood supply, leading to premature ovarian failure, and that they will not have the option of tubal reversal. ${ }^{25}$

\section{Conclusion}

In conclusion, the search for definitive methods is decreasing in our institution. The satisfaction rate was very high, and the complication rate was very low for both methods. For most women, both the laparoscopic and hysteroscopic techniques are effective options. The surgical approach depends on the patient's specific situation and her personal preferences and values. For women who desire a method that is immediately efficient and requires no further follow-up, the laparoscopic approach is preferable. However, for those who would like to avoid abdominal incisions and general anesthesia, hysteroscopic tubal occlusion may be the best choice. Gynecologists should take each woman's individual circumstances into account and provide directed counseling to help patients with the decision-making process.

\section{Conflicts of Interest}

The authors have no conflicts of interest to declare.

\section{References}

1 United Nations. Department of Economic and Social Affairs, Population Division [Internet]. Trends in contraceptive use worldwide 2015. 2015 [cited 2016 Jan 20]. Available from: http://www.un.org/en/development/desa/population/publications/pdf/family/trendsContraceptiveUse2015Report.pdf

2 Águas F, Bombas T, Pereira da Silva D. Evaluation on portuguese women contraceptive practice. Acta Ginecol Obstet Port 2016; 10(03):184-192

3 Chan LM, Westhoff CL. Tubal sterilization trends in the United States. Fertil Steril 2010;94(01):1-6

4 Cullen KA, Hall MJ, Golosinskiy A. Ambulatory surgery in the United States, 2006. Natl Health Stat Rep 2009;11(11):1-25

5 Castaño PM, Adekunle L. Transcervical sterilization. Semin Reprod Med 2010;28(02):103-109

6 Osathanondh V. Suprapubic mini-laparotomy, uterine elevation technique: simple, inexpensive and out-patient procedure for interval female sterilization. Contraception 1974;10(03):251-262

7 Ubeda A, Labastida R, Dexeus S. Essure: a new device for hysteroscopic tubal sterilization in an outpatient setting. Fertil Steril 2004;82(01):196-199
8 Trussell J. Contraceptive failure in the United States. Contraception 2011;83(05):397-404

9 Peterson HB, Xia Z, Hughes JM, Wilcox LS, Tylor LR, Trussell J. The risk of pregnancy after tubal sterilization: findings from the U.S. Collaborative Review of Sterilization. Am J Obstet Gynecol 1996; 174(04):1161-1168, discussion 1168-1170

10 Rattray D, Thiel P, Suchet I, Thiel J. Confirmation testing of Essure microinserts in unintended pregnancies using a 10 -year retrospective database. J Minim Invasive Gynecol 2016;23(06): 944-948

11 Stewart A, Cummins C, Gold L, Jordan R, Phillips W. The effectiveness of the levonorgestrel-releasing intrauterine system in menorrhagia: a systematic review. BJOG 2001;108(01):74-86

12 Levie M, Weiss G, Kaiser B, Daif J, Chudnoff SG. Analysis of pain and satisfaction with office-based hysteroscopic sterilization. Fertil Steril 2010;94(04):1189-1194

13 Levie MD, Chudnoff SG. Prospective analysis of office-based hysteroscopic sterilization. J Minim Invasive Gynecol 2006; 13(02):98-101

14 Famuyide AO, Hopkins MR, El-Nashar SA, et al. Hysteroscopic sterilization in women with severe cardiac disease: experience at a tertiary center. Mayo Clin Proc 2008;83(04):431-438

15 Panel P, Grosdemouge I. Predictive factors of Essure implant placement failure: prospective, multicenter study of 495 patients. Fertil Steril 2010;93(01):29-34

16 Miño M, Arjona JE, Cordón J, Pelegrin B, Povedano B, Chacon E. Success rate and patient satisfaction with the Essure sterilisation in an outpatient setting: a prospective study of 857 women. BJOG 2007;114(06):763-766

17 la Chapelle CF, Veersema S, Brölmann HA, Jansen FW. Effectiveness and feasibility of hysteroscopic sterilization techniques: a systematic review and meta-analysis. Fertil Steril 2015;103(06): 1516-25.e1, 3

18 Adelman MR, Dassel MW, Sharp HT. Management of complications encountered with Essure hysteroscopic sterilization: a systematic review. J Minim Invasive Gynecol 2014;21(05): 733-743

19 Thiel JA, Lukwinski A, Kamencic H, Lim H. Oral analgesia vs intravenous conscious sedation during Essure Micro-Insert sterilization procedure: randomized, double-blind, controlled trial. J Minim Invasive Gynecol 2011;18(01):108-111

20 Gordts S, Campo R, Puttemans P, Gordts S. Clinical factors determining pregnancy outcome after microsurgical tubal reanastomosis. Fertil Steril 2009;92(04):1198-1202

21 Monteith CW, Berger GS, Zerden ML. Pregnancy success after hysteroscopic sterilization reversal. Obstet Gynecol 2014; 124(06):1183-1189

22 Thiel J, Rattray D, Cher DJ. Pre-hysterectomy assessment of immediate tubal occlusion with the third-generation ESSURE insert (ESS505). J Minim Invasive Gynecol 2014;21(06): 1055-1060

23 Erickson BK, Conner MG, Landen CN Jr. The role of the fallopian tube in the origin of ovarian cancer. Am J Obstet Gynecol 2013; 209(05):409-414

24 Bollapragada SS, Bandyopadhyay S, Serle E, Baird C. Spontaneous pregnancy after bilateral salpingectomy. Fertil Steril 2005;83(03):767-768

25 Morelli M, Venturella R, Mocciaro R, et al. Prophylactic salpingectomy in premenopausal low-risk women for ovarian cancer: primum non nocere. Gynecol Oncol 2013;129(03):448-451 